\title{
ШТРАФ ЯК ВИД ПОКАРАННЯ ЗА ВЧИНЕННЯ КРИМННАЛЬНИХ ПРАВОПОРУШЕНЬ, ОЗНАКОЮ СКЛАДІВ ЯКИХ Е ІСТОТНА ШКОДА
}

\author{
КАНЦІР Володимир - Д. ю.Н., проф., професор кафедри кримінального \\ права і процесу Інституту права, психології та інноваційної освіти Національного \\ університету «Јьвівська політехніка" \\ СКРЕКЛЯ Леся - к.ю.н., доц. кафедри кримінального права та процесу \\ Львівського торговельно-економічного університету \\ ЛЕМЕХА Роман - к.ю.н., доцент кафедри менеджменту та соціально- \\ гуманітарних дисциплін, Львівська філія ПВНЗ «Европейський університет» \\ DOI 10.32782/NP.2021.2.17
}

У статті проаналізовано положення чинного Кримінального кодексу Украӥни в частині призначення покарання у виді штрафу. Досліджено окремі проблеми, що виникають у судових органів при його застосуванні. Співставлено розмір істотної шкоди у виді матеріальних збитків та розмір штрабу як виду покарання за вчинення кримінальних правопорушень, ознакою складів яких $є$ істотна шкода.

Ключові слова: покарання, штраф, призначення штрафб, розмір, істотна шкода.

Постановка проблеми

Покарання $\varepsilon$ одним із найпоширеніших заходів у системі реагування з боку держави на факт вчинення кримінального правопорушення. Будь-який вид покарання, навіть найменш суворий, завжди пов'язаний із суттєвим обмеженням прав i свобод засудженого [1, c.161]. Останніми роками кримінально-правова політика в Україні орієнтована на більш гуманне ставлення до осіб, визнаних судом винними у вчиненні кримінальних правопорушень. Свідченням цього стала ратифікація Україною низки міжнародних документів, спрямованих на розширення заходів, альтернативних позбавленню волі, одним з яких є штраф [2, с.107]. Відповідно до підпункту d пункту 8.2 Мінімальних стандартних правил Організації Об'єднаних Націй щодо заходів, не пов'язаних з тюремним ув'язненням, органи, що виносять вироки, можуть застосовувати економічні санкції й грошові покарання, такі, як разові штрафи і щоденні штрафи [3]. -
Особливістю цього виду покарання є те, що штраф виступає найменш суворим видом покарання та належить до так званих змішаних заходів примусу, оскільки може бути призначений як основне покарання, так як і додаткове. Окрім того, за твердженням О.М. Подільчака, він не потребує особливих додаткових витрат для створення механізму виконання відповідного покарання, чинить мінімальний вплив на правопорушника, оскільки останній не залучається до кримінальної субкультури установ виконання покарань i, водночас, є суттєвим каральним чинником [4, с.232]. Розвиваючи цю тезу, Б.М. Телефанко зауважує, що штраф володіє багатьма перевагами перед іншими видами покарань, він може надати необхідний вплив на засудженого з метою попередження вчинення нового кримінального правопорушення i, як каральний засіб, забирає у нього значні грошові кошти [5, с.176].

Аналіз останніх досліджень

Питання штрафу, як виду покарання, висвітлювалось у дослідженнях К.А. Автухова, А.А. Васильєва, Н.О. Гуторової, В.П. Козирєвої, В.Т. Маляренка, К.Б. Марисюка, О.І.Плужника, Ю.А. Пономаренка, О.С. Пироженка, В.О.Попраса, Г.С. Резнічено, А.А. Смирнова, В.В.Сташиса, В.І. Тютюгіна та інших. Проте чимало питань, що стосуються призначення штрафу як виду покарання, залишаються дискусійними або невирішеними, а зокрема: щодо вдосконалення кримінально-правового регулювання покарання у виді штрафу; невідповідності розміру суспільно 
небезпечних наслідків у виді істотної шкоди, якщо вона полягала у заподіянні матеріальних збитків та розміру штрафу як виду покарання тощо.

3 урахуванням зазначених напрацювань ми поставили за мету проаналізувати особливості застосування штрафу як виду покарання за вчинення кримінальних правопорушень, ознакою складів яких є істотна шкода.

\section{Виклад основних положень}

У КК України штраф як вид покарання за вчинення кримінальних правопорушень, ознакою складів яких $є$ істотна шкода, передбачений наступними статтями: ч. 1 ст. 137, ч. 1,2 ст.209-1, ст.231, ст.232, ч.1 ст.244, ст.246, ч.1 ст.248, ч.1 ст.249, ч.1 ст.364, ч.1 ст.364-1, ч.1 ст.367, ч.1 ст.425, ч.1 ст.426 КК України. Санкції відповідних статей є простими (ст.231КК України), кумулятивними (ч.1 ст.137, ч.1, 2 ст.209-1, ст.232, ч.1 ст.364, ч.1 ст.364-1, ч.1 ст.367, КК України), одиничними (ч.1,2 ст.2091, ст.232 КК України), альтернативними (ч.1 Ст.137, ч.1 ст.244, ст.246, ч.1 ст.248, ч.1 ст.249, ч.1 ст.364, ч.1 ст.364-1, ч.1 ст.367, ч.1 ст.425, ч. 1 ст.426 КК України), відносно визначеними (ч.1, 2 ст.209-1, ст.231, ст.232 КК України).

У теорії кримінального права вироблено низку правил побудови кримінально-правових санкцій, яких слід дотримуватись законодавцю під час конструювання кримінальноправових санкцій для того, щоб у суду була можливість призначити винній особі законне, справедливе та достатнє покарання [6, с.183]. Так, до правил побудови кримінально-правових санкцій належить правило, у відповідності до якого зростання санкцій за основний, кваліфікований та особливо кваліфікований види кримінального правопорушення повинна йти або «у стик» або «з перекриттям» залежно від особливостей конкретного його складу [7, с.6].

Аналіз санкцій статей, які передбачають відповідальність за кримінальні правопорушення, ознакою складів яких 6 істотна шкода, показав, що у всіх санкціях відповідних статей КК України не порушено вищезазначеного правила. Як приклад, наведемо санкцію статті, яка передбачає відповідальність за умисне порушення вимог законодавства про запобігання та протидію легалізації (відмиванню) доходів, одержаних злочинним шляхом, фінансуванню тероризму та фінансуванню розповсюдження зброї масового знищення (ст.209-1 КК України). Так, санкція ч. 1 ст. 2091 КК України передбачає основне покарання у виді штрафу у розмірі від однієї тисячі до трьох тисяч неоподатковуваних мінімумів доходів громадян, натомість, санкція ч.2 ст.209-1 КК України - штраф у розмірі від трьох тисяч до п'яти тисяч неоподатковуваних мінімумів доходів громадян. Іншим прикладом 6 санкція ст. 249 КК України, яка передбачає кримінальну відповідальність за незаконне зайняття рибним, звіриним або іншим водним добувним промислом. Зокрема, санкції ч.1 ст.249 КК України ають альтернативне покарання у виді штрафу розміром від однієї тисячі до трьох тисяч неоподатковуваних мінімумів доходів громадян. У ч.2 ст.249 КК України від трьох тисяч до п'яти тисяч неоподатковуваних мінімумів доходів громадян.

Не менш важливим правилом побудови кримінально-правових санкцій є правило, відповідно до якого санкції, які відповідають кваліфікованим складам кримінальних правопорушень, повинні базуватися на санкціях, що відповідають основним складам кримінальних правопорушень, тобто повинні бути логічно несуперечливі [8, с. 242]. У теорії кримінального права зазначається, що зміна меж санкції або диференціація типового покарання - основна функція інституту кваліфікуючих ознак, які змінюють межі відповідальності у КК України. Зміна меж санкцій кваліфікуючими ознаками відображає зміну рівня (ступеня) суспільної небезпеки вчиненого при наявності у скоєному ознак кваліфікованого складу кримінального правопорушення.

При конструюванні окремих санкцій статей, які передбачають відповідальність за кримінальні правопорушення, ознакою складів яких є істотна шкода, вищезгадане загальновідоме правило було порушено. Так, санкція ч. 1 ст.248 КК України за незаконне полювання як альтернативне покарання передбачає штраф від однієї тисячі до трьох тисяч неоподатковуваних мінімумів доходів громадян, натомість, санкція ч.2 ст.248 КК України за вчинення тих самих дій службовою особою 3 використанням службового становища, або за попередньою змовою групою осіб, або способом масового знищення звірів, птахів чи ін- 


\section{Кримінальне право, кримінальний процес та криміналістика}

ших видів тваринного світу, або з використанням транспортних засобів, або особою, раніше судимою за кримінальне правопорушення, - штраф від двохсот до чотирьохсот неоподатковуваних мінімумів доходів громадян. Звідси випливає, що за незаконне полювання, скажімо, способом масового знищення звірів (ч.2 ст.248 КК України), законодавцем встановлена менш сувора міра покарання у виді штрафу, аніж за незаконне полювання без кваліфікуючих ознак (ч.1 ст.248 КК України).

У подальшому необхідно також співставити розмір істотної шкоди у виді матеріальних збитків та розмір штрафу як виду покарання за вчинення відповідних посягань. Так, дії особи, які полягають у недбалому ставленні військової службової особи до служби (ч.1 ст.425 КК України), вважатимуться кримінально-караними, якщо внаслідок їх вчинення будуть завдані матеріальні збитки, які в двісті п’ятдесят і більше разів перевищують неоподатковуваний мінімум доходів громадян. У відповідності до ст. 7 Закону України «Про державний бюджет України на 2021 рік» прожитковий мінімум на одну особу в розрахунку на місяць для працездатних осіб становить 2270 гривень [9]. Тому податкова соціальна пільга становить 1135 гривень. Відповідно, істотна шкода у складі злочину, передбаченого ст.425 КК України, становить 283750 грн. Натомість, як альтернативне покарання за недбале ставлення до військової служби передбачено штраф від двохсот вісімдесяти п'яти до трьохсот двадцяти п'яти неоподатковуваних мінімумів доходів громадян, тобто від 4845 до 5525 грн. Звідси випливає, що розмір штрафу за вчинений злочин $є$ значно меншим, аніж розмір заподіяної злочином шкоди.

Дещо схожа ситуація прослідковується і в інших статтях КК України, у яких істотна шкода є суспільно небезпечним наслідком вчинення кримінального правопорушення. Наприклад, розмір матеріальних збитків при незаконному полюванні та бездіяльності військової влади становить 283750 грн. (ч.1 ст.248, ч.1 ст.426 КК України), натомість, розмір штрафу - від 17000 до 51000 грн. (ч.1 ст.248 КК України); від 17000 до 68000 грн. (ч.1 ст.426 КК України).

Слід зазначити, що у ч.2 ст.53 КК України вказується, що «за вчинення кримінального правопорушення, за яке передбачене основне покарання у виді штрафу понад три тисячі неоподатковуваних мінімумів доходів громадян, розмір штрафу, що призначається судом, не може бути меншим за розмір майнової шкоди, завданої кримінальним правопорушенням, або отриманого внаслідок вчинення кримінального правопорушення доходу...». Однак у більшості проаналізованих нами випадках розмір штрафу є меншим, ніж три тисячі неоподатковуваних мінімумів доходів громадян. На цю проблему звертав увагу Р.А. Максимович, який запропонував виключити з ч.2 ст.53 КК України вказівку на вищевказаний розмір штрафу і викласти норму, що міститься у відповідній статті, таким чином: «За вчинення кримінального правопорушення, за яке передбачене основне покарання у виді штрафу, розмір штрафу не може бути меншим за розмір майнової шкоди, завданої кримінальним правопорушенням, або отриманого внаслідок вчинення кримінального правопорушення доходу, незалежно від граничного розміру штрафу, передбаченого санкцією статті (санкцією частини статті) Особливої частини цього Кодексу» [10, с.337-338]. Така позиція вищезгаданого науковця є справедливою, оскільки міра основного покарання у виді штрафу за вчинення окремих кримінальних правопорушень, ознакою складів яких $\varepsilon$ істотна шкода, $\epsilon$ мізерною у порівнянні із завданими збитками та не має карально-виховного характеру. Разом із тим, запропоновані Р.Л. Максимовичем відповідні зміни до ч.2 ст.53 КК України не вирішують повною мірою аналізовану проблему. У цьому випадку можливі два шляхи вирішення проблеми невідповідності розміру суспільно небезпечних наслідків у виді істотної шкоди (якщо вона полягала у заподіянні матеріальних збитків), та розміру штрафу як виду покарання: перший - збільшити міру покарання за вчинення відповідних кримінальних правопорушень; другий - зменшити у диспозиції статті КК України розмір заподіяної кримінальним правопорушенням істотної шкоди. Однак, жоден із запропонованих підходів не є виправданим, оскільки збільшення міри покарання за окремі кримінальні правопорушення призведе до їх «зрівняння» 3 більш тяжкими кримінальними правопорушеннями (наприклад, злочинами, ознакою складів яких 
є тяжкі наслідки). Натомість, зменшення розміру заподіяної кримінальним правопорушенням істотної шкоди також $є$ недопустимим, оскільки в окремих випадках дії особи отримають одночасно кримінально-правову оцінку та вважатимуться адміністративним проступком. У цьому випадку слід звернутися до аналізу судової практики в Україні в цій частині.

Як приклад, наведемо вирок Берегівського районного суду Закарпатської області від 3 жовтня 2013 р., де особа, будучи військовою службовою особою, на яку покладались організаційно-розпорядчі функції, та матеріальновідповідальною особою - командиром автомобільної роти підвозу боєприпасів військової частини А 1771, через несумлінне ставлення до виконання своїх службових обов'язків та злочинну недбалість, неналежно виконав вимогуу ст.ст. 11, 16, 58, 59, 111, 112 Статуту внутрішньої служби Збройних Сил України, ст. 4 Дисциплінарного статуту Збройних Сил України, ст. 3 Закону України «Про правовий режим майна Збройних силах України», п.п. 3.1.9, 5.18.3.1 Положення про військове (корабельне) господарство Збройних Сил України, хоча мав реальну можливість їх виконати, та у період з 15 січня 2011 року по 31 грудня 2012 року дійсним станом справ у підрозділі не володів, правильне збереження 82 мм мін BO-I та комплектуючих до них у сховищі№ 51 ракетно-артилерійського озброєння та інженерних боєприпасів військової частини А 1771, що дислокувалась у с. Гать Берегівського району Закарпатської області, не організував, заходів по запобіганню втрат майна не вживав, один раз на місяць не звіряв дані ротного обліку матеріальних засобів з обліковими даними військової частини та ведення їх обліку не контролював, а навпаки - допустив зберігання основних вишибних порохових зарядів Ж-832Д та додаткових дальнобійних порохових зарядів Ж-832Д окремо від 82 мм мін ВО-I в іншому сховищі військової частини А 1771, що призвело до втрати цих комплектуючих, а саме: вишибних порохових зарядів Ж-832Д у кількості 1380 шт., додаткових дальнобійних порохових зарядів Ж-832Д у кількості 1191 шт., спричинивши матеріальні збитки державі на загальну суму - 218257,50 грн.

Суд визнав особу винуватою у вчиненні злочину, передбаченого ч.1 ст.425 КК України, та призначив їй покарання у вигляді службового обмеження на строк один рік, з відрахуванням із суми iї грошового забезпечення в дохід держави протягом вказаного строку 10 (десяти) відсотків. Окрім того, судом постановлено рішення стягнути із засудженої особи на користь держави (в особі військової частини A1556) заподіяні злочином матеріальні збитки в сумі 218257, 50 гривень [11].

Натомість, в іншому кримінальному провадженні підсудний О., будучи військовою службовою особою, а саме начальником речового складу довгострокового зберігання військової частини A4324, у період 3 травня 2007 року по липень 2010 року недбало поставився до військової служби, яке виразилось у тому, що він належним чином не здійснював облік речового майна складів довгострокового зберігання та поточного забезпечення, його збереження, приймання та видачу, а також не здійснював щомісячних звірок 3 фінансово-економічною службою військової частини А4324 даних обліку майна речових складів довгострокового зберігання та поточного забезпечення.

У зв'язку з цим з військової частини зникли наступні речі, а саме: 12 пар погонів зйомних для старших офіцерів, 8 пар погонів зйомних для прапорщиків, 2 пари погонів-муфт, 98 зірочок золотистих, 1000 зірочок золотистих, 6,42 м. галуну шовкового золотистого, 7,90 галуну шовкового кольору, 427 гудзиків золотистих, 69 кокард золотистих солдатських, 243 прапорців на берет, а всього на суму - загальною вартістю 115682,37 гривень, чим вчинив недбале ставлення до військової служби, що заподіяло істотну шкоду, яка в двісті п'ятдесят і більше разів перевищує неоподатковуваний мінімум доходів громадян станом на липень 2010 року. На підставі вищенаведеного суд визнав начальника речового складу довгострокового зберігання військової частини винним у вчиненні злочину, передбаченого ч.1 ст.425 КК України, та призначив йому покарання у виді штрафу в розмірі 1000,00 гривень [12]. 3 аналізу цих вироків випливає, що суд в одному випадку за вчинення злочину, передбаченого ч. 1 ст.425 КК України, окрім призначеного покарання, стягує із засудженого заподіяні матеріальні збитки, натомість, в іншому - ні. 


\section{Висновки}

Таким чином, стягнення судом із засудженого заподіяних матеріальних збитків (зокрема, у порядку цивільного судочинства), які охоплюються поняттям «істотна шкода», вирішує проблему невідповідності розміру суспільно небезпечних наслідків у виді істотної шкоди, якщо вона полягала у заподіянні матеріальних збитків та розміру штрафу як виду покарання.

\section{Аiтература}

1. Евдокімова О.В. Особливості призначення штрафу під час пом'якшення покарання. Юридичний науковий електронний журнал. №4. 2016 р. С.161-165

2. Остапчук А.Г. Проблемні аспекти виконання покарання у виді штрафу в Україні. Кримінально-виконавча система: вчора, съогодні, завтра. №2 (2). 2017. С.107-115

3. Мінімальні стандартні правила Організації Об’єднаних Націй у відношенні заходів, не пов'язаних 3 тюремним ув'язненням (Токійські правила) (Прийняті 14.12.1990 Резолюцією 45/110 Генеральної Асамблеї ОOH) URL: https://zakon.rada.gov.ua/laws/show/ru/995 907

4. Подільчак О.М. Правове регулювання покарань у виді штрафу. Вісник пенітениіарноі асоигачй України. №3 (9). 2019. С.231-240

5. Телефанко Б.М. Вплив покарання у вигляді штрафу на рецидивну злочинність. Актуальні проблеми вітчизняної юриспруденциї.№6. Том 1. 2018 р. С.176-178

6. Степаненко Д.Ю. Кримінально-правова характеристика санкцій ст.212-1 КК України. Наука і правоохорона. №1 (19). 2013 р. С.183-189.

7. Проценко В.П. Построение уголовноправовых санкций при повторности преступлений: автореф. дисс. к.ю.н. Саратов, 1989. $-20 \mathrm{c}$.

8. Авраменко О.В. Врахування стану сильного душевного хвилювання при конструюванні санкції ст. ст. 116, 123 КК України. Науковий вісник Аввівського державного університету внутрішніх справ. Сер. юридична. Вип. 1. 2008. C. 237-250.

9. Про Державний бюджет України на 2021 рік: Закон України від 15 грудня 2020 р. № 1082-IX. URL: https://zakon.rada.gov.ua/laws/ show/1082-20\#Text

\section{SUMMARY}

The article analyzes the current criminal law in part of sentencing the punishment in the form of a fine. Particular problems that arise concerning its application. Main problems of Criminal Code of Ukraine (2001) in the aspect of improving practice of punishment in form of penalty application are analyzed. Series of lawsuits, concerning application of punishment in form of penalty towards persons, who are guilty in crimes of minor gravity, are examined. The necessity of award of punishment in form of penalty, according to the severity of commited crime, convict and his family's financial position and the sum of convict's salary or the other income, is grounded. Thus, the punishment in the form of a fine is a property type of punishment which punitive influence is directed at the financial interests of the convicted person. Fine is a punishment where the usage of remedies is excluded, precisely for this reason the purpose of the fine must be determined, first of all, not by the category of committed crime, but by the degree of the person's who committed it, criminal damage. Accordingly, the amount of punitive effects of punishment in form of fines is directly related to its size.

In connection with the above-mentioned arguments, suggest to bring down the maximal size of punishment is legislatively envisaged in the type of fine to the economically reasonable limit, namely at least in 3-5 times. Maintenance of present maximum seems expedient only in case of input of criminal responsibility of legal entities and only in relation to the last. Offered, that sizes of fines both in General part and in approvals of the articles of Special part of $C C$ of Ukraine, to outline not in untaxable minimums of profits of citizens, but in monetary items.

Key words: penalty, fine, sentencing of a fine, size, substantial harm.

10. Максимович Р.Л. Істотна шкода як наскрізне кримінально-правове поняття. Науковий вісник Аввівсъкого державного університету внутрішніх справ. №3. 2013 р. С. 335-342.

11. Вирок Берегівського районного суду Закарпатської області від 3 жовтня 2013 року. Справа №297/1773/13-к. URL: http://www. reyestr.court.gov.ua/Review/33928200

12. Вирок Пустомитівського районного суду Аьвівської області від 15 березня 2011 року. Справа №1-1316/141/11.URL: http://www. reyestr.court.gov.ua/Review/14189014 